\title{
Congener profiles of polychlorinated biphenyls and the effect on marine mussels at an outfall site, Port Elizabeth, South Africa
}

\author{
E Kampire ${ }^{1,3}$, G Rubidge', JB Adams² and L Human ${ }^{2}$ \\ 'Nelson Mandela Metropolitan University, Department of Chemistry, P.O. Box 77000 Port Elizabeth, 6031, South Africa \\ ${ }^{2}$ Nelson Mandela Metropolitan University, Department of Botany, P.O. Box 77000 Port Elizabeth, 6031, South Africa \\ ${ }^{3}$ University of Rwanda, College of Education, P.O. Box 5039 Kigali, Rwanda
}

\begin{abstract}
This study investigated the effect of freshwater as a point source of PCBs contributing to a marine outfall region. Inflowing and outflowing water from the North End Lake, Port Elizabeth, was collected to determine the contamination levels of polychlorinated biphenyls (PCBs). Mussels at the outflow to the sea were also sampled. The samples were analysed by an internal standard method for 6 indicator PCB congeners using gas chromatography/mass spectrometry (GC/MS) in selected ion monitoring (SIM) mode. The total PCB concentrations in the water (dissolved plus particulate phases) ranged from 0.180 to $0.355 \mathrm{ng} \cdot \mathrm{L}^{-1}$ and from 20.84 to $31.34 \mathrm{ng} \cdot \mathrm{g}^{-1}$ wet weight (ww) in mussels. Lighter PCB congeners exhibited highest concentrations in the water samples while heavier PCBs were dominant in mussels. PCB-52 was the most abundant in the water samples while PCB-153 was abundant in mussels. To protect human health from the possible effects of eating fish and shellfish contaminated with PCBs, the Environmental Protection Agency regulates that the level of PCBs in water be no greater than $0.17 \mathrm{ng} \cdot \mathrm{L}^{-1}$ of water. The levels of PCBs in water from the North End Lake were found to be high $\left(0.180-0.355 \mathrm{ng} \cdot \mathrm{L}^{-1}\right)$ compared to the levels recommended by EPA.
\end{abstract}

Keywords: dissolved phase, GC/MS, North End Lake, particulate phase, sedentary organisms

\section{INTRODUCTION}

Polychlorinated biphenyls (PCBs) are one of the most widespread, ubiquitous and hazardous contaminants of marine ecosystems (Moore et al., 2002). Coastal zones, particularly areas near urban and industrial centres are exposed to elevated concentrations of these contaminants. The persistent nature of PCBs, along with their mobility, influences their presence in almost all water bodies, making them potential environmental and human health concerns (Breivik et al., 2004). The release of various organic pollutants from different sources such as aerial deposition, runoff, and domestic wastewater from households and industrial effluents into the environment is an issue of great concern in many countries. Lakes, seas, rivers, and dams have become the immediate environmental reservoirs for possible organic pollutants (Chee et al., 1996).

In South Africa, contaminated stormwater from urban areas and runoff from rivers are sources of hydrocarbon loads to the marine environment (Taljaard et al., 2000). PCBs can be transported over long distances by both the atmosphere and water; hence, these contaminants are often detected in locations that are isolated from original sources (Olenycz et al., 2015).

PCB congeners share a simple basic structure and various combinations of congeners can occur, with diverse physicochemical properties. Changes in congener profile can lead to differences in uptake, metabolism, bioaccumulation, binding to biological receptors and toxicity in an ecosystem (Babut et al., 2012). When released into the environment, PCBs bind to the organic carbon of sediments and thus serve as a long-term source of contaminants in water bodies and biota (Luthy, 2004).

\footnotetext{
* To whom all correspondence should be addressed. 区 +250788451398; e-mail: edkampire@gmail.com Received 18 August 2015; accepted in revised form 6 July 2016
}

Therefore, higher levels of PCBs are detected mostly in coastal and estuarine marine waters where they can severely impact resident biota, in particular, inactive filter-feeding bivalves and bottom-dwelling organisms (Olenycz et al., 2015). The use of bivalves as bioindicator organisms is particularly beneficial due to the similarity in pollutant exposure and uptake mechanisms and as such the species differences in uptake are negligible. The brown mussel (Perna perna) is prolific on rocky reefs along the east coast of South Africa (Berry and Schleyer, 1983) but is absent along the west coast of South Africa (Hammond and Griffiths, 2006). This mussel has a lower growth rate and tolerance to desiccation than the invasive Mediterranean mussel (Mytilus galloprovincialis), making it less competitive than the alien species. Mussels, especially brown mussels, live in the rocky intertidal shore where discharges of waste take place (Regoli and Principato, 1995). The liposolubility of PCBs, characterized by an octanol-water partition coefficient $\left(\log K_{\text {ow }}>5\right)$, renders such compounds subject to trophic transfer and biomagnification (Jaffar et al., 2011). Therefore, mussels in the vicinity of the North End Lake outfall can retain and bioconcentrate chemical compounds by direct transfer through the contaminated sites. Humans and wildlife that consume contaminated organisms can also accumulate PCBs in their tissues which lead to body burdens (Beyer and Biziuk, 2009).

Effects on human health can result from exposure to surface water contaminated by organic pollutants through contact recreation, drinking water and the consumption of contaminated food such as shellfish (Du Preez et al., 2003). According to Guéguen et al. (2011), the health risks associated with consuming shellfish contaminated by persistent organic pollutants (POPs) are difficult to assess since contaminants can be derived from multiple sources. The risk to a human receptor from being exposed to a chemical via a single pathway can be expressed as an exposure ratio, commonly called a hazard quotient (HQ), and calculated as the ratio of the potential exposure to the substance and the level at which no adverse effects are expected. 
In South Africa, research concerning PCB contamination in water and mussels is sparse. There is no reported literature on PCB levels in the North End Lake in Port Elizabeth. Therefore, the present study was designed to assess the contamination levels of PCBs in water and mussels from the North End Lake collected at the outflow of this lake into the Indian Ocean. The study focused only on 6 indicator PCBs, since these are known to persist and bioaccumulate in the food chain. The North End Lake was selected as it is surrounded by industries and receives waste discharges and stormwater from the surrounding areas. It also serves as a point-source contributing PCBs to an outfall site. Data from this study will provide an important baseline for future pollutant monitoring programmes.

\section{MATERIALS and METHODS}

\section{Sampling and sample preparation}

Water and brown mussel (Perna perna) samples were collected in September and October 2014. Water samples were collected from 11 locations, including the surface water and wastewater inflow into the lake as well as the outflow (Fig. 1). A total of 36 water samples were collected with 3 samples per site, except at Site 9 where 3 additional samples were collected. Water samples were collected by hand in pre-cleaned $1 \mathrm{~L}$ brown amber glass bottles with Teflon-lined caps. Five of the sampling sites (S6, S7, S8, S9 and S10) were in close proximity to stormwater inflow into the lake; four sites (S1, S2, S4 and S5) were deeper out in the lake while two sites (S3 and M1) were in close proximity to the outflow from the lake. Samples were transported to the laboratory where they were stored in a cold room at $4^{\circ} \mathrm{C}$ until analysis. Because water is a heterogeneous matrix (contains suspended solid particles such as sediment or algae), the dissolved and particulate fractions of a sample were distinguished by filtration (Nielsen and Nielsen, 2006). In the laboratory and before the extraction, the particulate and dissolved phases were separated through filtration using the glass fibre filter (pore size $1.0 \mu \mathrm{m}$ ). Materials retained on the filters were defined as the particulate phase. The filters with suspended solids and associated particulate chemical fractions were wrapped in aluminium foil for preservation and stored at $4^{\circ} \mathrm{C}$ prior to analysis.

Sixty (60) brown mussels (Perna perna) were handpicked from rocks at 6 locations, namely, M1-M6 around the point source of the North End Lake outflow into the sea (Fig. 1). $\mathrm{M} 1$ was considered as the point source of reference. Three sites (M2, M3 and M4) were located to the north of M1 and sites M5 and M6 were to the south of M1. Individual mussels (12) were collected at Sites 1, 3, 4 and 6 while 18 samples were collected at Sites 2 and 5; however, due to the small size of the mussels, some individuals were pooled to form a composite sample. Mussels collected at each site were placed in polyethylene bags and transported to the laboratory on ice. Upon arrival in the lab, the mussels were scrubbed with a brush (stainless steel) to remove adhering epibionts after which the weight and shell length of each mussel were recorded before being stored in a freezer at $-20^{\circ} \mathrm{C}$. Two or three individual mussels of similar shell length $(45-84 \mathrm{~mm})$ from the same site were pooled together to obtain the representative sample ( 35 samples). Typically, 6 samples from each site were analysed except for Site 6 from which 5 samples were analysed. The mussels were dissected and the soft tissue of the sample was weighed and placed in a glass jar sealed with a lid and kept frozen at $-20^{\circ} \mathrm{C}$ to avoid loss of water and to reduce most enzymatic and oxidative reactions until further analysis.

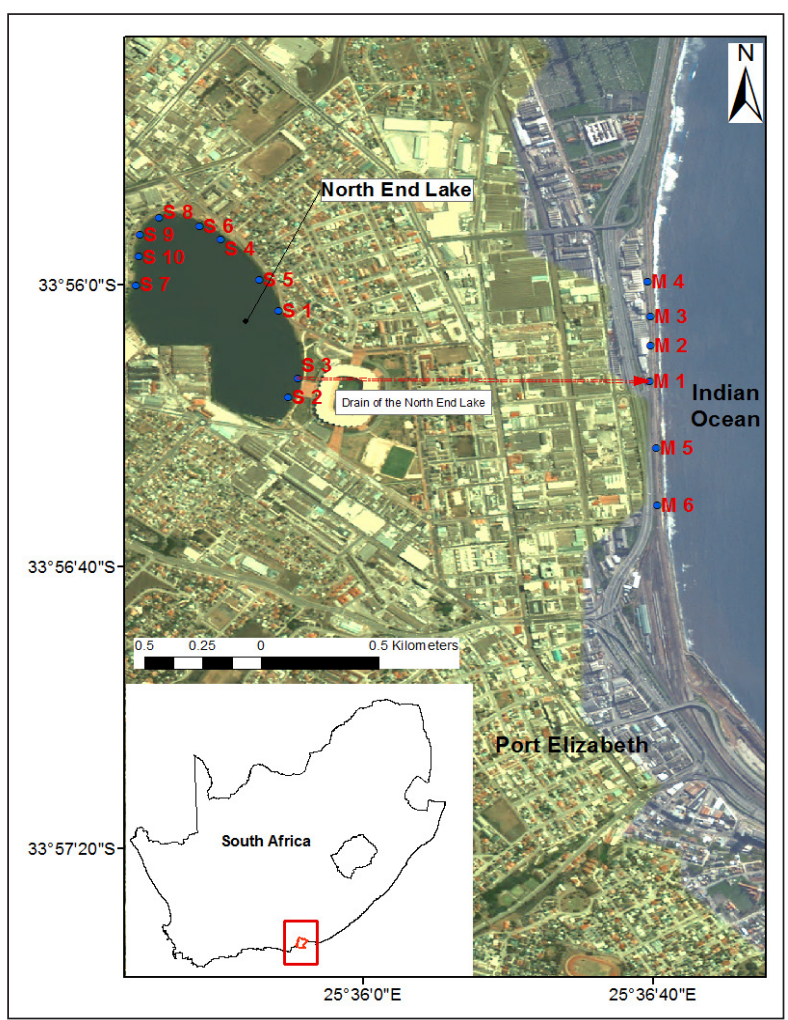

Figure 1

Location of Port Elizabeth within South Africa, and location of sampling sites in North End Lake and the Indian Ocean

\section{Analytical procedures}

\section{Extraction of water and mussel samples}

- Water: The dissolved PCBs were extracted by liquid-liquid extraction using a separatory funnel, $2000 \mathrm{~mL}$ with stopcock (glass or Teflon). The method was adapted from US EPA Method 3510C as described by You et al. (2011) and Kumar et al. (2012), with some modifications. Briefly, $1 \mathrm{~L}$ of water was extracted 3 times with $60 \mathrm{~mL}$ of methylene chloride by shaking the funnel for $2 \mathrm{~min}$, with periodic venting to release excess pressure, and allowed to cool for $10 \mathrm{~min}$. The extracts were combined and filtered through $4 \mathrm{~g}$ of anhydrous sodium sulphate (activated at $300^{\circ} \mathrm{C}$ for $12 \mathrm{~h}$ before use) to take up water to become hydrated. The glass fibre filters containing particulates from each sample were Soxhlet extracted with a $250 \mathrm{~mL}$ mixture of $50 \%$ methylene chloride $/ 50 \%$ hexane for $18 \mathrm{~h}$. A surrogate spike (tetrachloro-meta-xylene) was added to each sample before the extraction. The resulting extracts (dissolved/particulate phase) were concentrated under vacuum to $1 \mathrm{~mL}$ and subjected to clean-up.

- Mussels: Soxhlet extraction was used to extract PCBs in mussels. Briefly, mussels (2 g) were mixed with $8 \mathrm{~g}$ of $\mathrm{Na}_{2} \mathrm{SO}_{4}$ (activated at $300^{\circ} \mathrm{C}$ for $12 \mathrm{~h}$ ) and ground using a mortar and pestle to homogenize and dehydrate the samples. Recovery standard (tetrachloro- $m$-xylene) was added to all the mussel samples prior to extraction. The mixture was transferred to a pre-cleaned extraction thimble and the dehydrated tissue was extracted with $250 \mathrm{~mL}$ of methylene chloride and hexane $(1: 1 \mathrm{v} / \mathrm{v})$ for $16 \mathrm{~h}\left(5-6\right.$ cycles $\left.^{-1}\right)$ in a Soxhlet apparatus. The extracts were concentrated under vacuum to $1 \mathrm{~mL}$ and subjected to clean-up. 
Water and mussel extracts were cleaned-up by removing the elemental sulphur with treatment of the extracts by concentrated sulphuric acid and by fractionation using Florisil. Glass column chromatography was packed with $2 \mathrm{~g}$ of anhydrous sodium sulphate, covered with $10 \mathrm{~g}$ of Florisil and topped with another $2 \mathrm{~g}$ of anhydrous sodium sulphate in order to avoid re-suspension of the top layer when pouring solvents into the column. The Florisil column was rinsed with $\mathrm{n}$-hexane $(40 \mathrm{~mL})$ to remove any impurities and the elution was accomplished by $80 \mathrm{~mL}$ of hexane. The eluted extracts were concentrated and evaporated using a rotary evaporator and dried under a gentle stream of pure nitrogen. The residue was dissolved in $1 \mathrm{~mL}$ of hexane. An internal standard (PCB 209) was added to each sample before the instrumental analysis.

\section{Instrumental analysis}

The extracts were analysed using an Agilent GC-7890 coupled with Agilent 5975 mass spectrometer detector (GC/MSD) and a $30 \mathrm{~m}$ x $0.25 \mathrm{~mm}$ i.d. x $0.25 \mu \mathrm{m}$ DB- $1 \mathrm{~ms}$ capillary column (CJ \&W Scientific, CA, USA). Helium was used as a carrier gas at a flow rate of $1.2 \mathrm{~mL} \cdot \mathrm{min}^{-1}$ and the splitless mode was used. The temperature was programmed from an initial temperature of $100^{\circ} \mathrm{C}$ ( 1 min hold) and then increased by $15^{\circ} \mathrm{C} \mathrm{min}^{-1}$ to $325^{\circ} \mathrm{C}$ and held for $5 \mathrm{~min}$. The mass spectrometer was operated in the electron impact (EI) ionization mode $(70 \mathrm{eV})$ with ion source, quadrupole and transfer line temperatures of 230, 150 and $280^{\circ} \mathrm{C}$, respectively. The mass spectra of individual compounds were obtained by injecting $1 \mu \mathrm{L}$ of each sample (or standard) into the GC. For improved sensitivity, the MS was operated under selected ion monitoring (SIM) at $\mathrm{m} / \mathrm{z}=258,256,186$ (CB-28), 292, 290, 220 (CB-52), 326, 324, 256 (CB-101), 362, 360, 290 (CBs-138 and 153), 396, 394, 324 (CB-180) and 500, 498, 428 (CB-209).

\section{Quality assurance/control and data analysis}

To ensure the quality of the data, a procedural blank and a standard were run after every batch of 5 samples and were treated in exactly the same way as the samples. A mixture of PCB standard solution containing PCB 28, PCB 52, PCB 101, PCB 138, PCB 153 and PCB 180 supplied by Sigma Aldrich (South Africa) was used for the instrument calibration. Peaks were identified in the sample extract by comparing the retention times with those of the corresponding compounds in the pure standards. The limits of detection (LOD) for the target PCB congeners were calculated based on the blank average concentration corresponding to the $\mathrm{m} / \mathrm{z}$ signal plus three times the standard deviation (Tasdemir et al., 2005). The detection limits in water samples ranged from

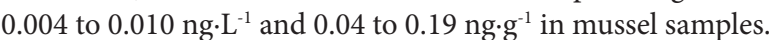
Recovery studies involving analysis of blank samples fortified with PCB standards at different levels were carried out. The average percentage recoveries ranged from 79.4 to $95.4 \%$ in water and 87.8 to $95.2 \%$ in mussels.

The data were analysed with STATISTICA 11.0 software. Significant differences of the means and variances were determined using one-way analysis of variance (ANOVA). Concentrations below the limit of detection were assigned a half value of the detection limit for statistical analysis. All the tests were considered statistically significant when the $p$-value $<0.05$.

\section{RESULTS}

\section{PCB levels in water samples}

Concentrations of the total PCBs in water (dissolved plus particulate phases) are presented in Table 1. All the analysed PCB congeners were present in most of the water samples. Total PCB concentrations ranged from $0.180 \pm 0.09$ to $0.355 \pm 0.017 \mathrm{ng} \cdot \mathrm{L}$ 1 . The average concentrations of PCBs in the dissolved and particulate phases were $0.121 \pm 0.025$ and $0.144 \pm 0.06 \mathrm{ng} \cdot \mathrm{L}^{-1}$, respectively. The dissolved phase represented $46 \%$ of PCBs and the suspended phase represented an average $54 \%$ of PCBs in all the water samples. The highest concentration of total PCBs in the water samples $\left(0.355 \mathrm{ng} \cdot \mathrm{L}^{-1}\right)$ was detected at Site 7 . In the particulate phase, significant differences were observed between Sites S3, S8, S9 and S11 $(F=5.53, p<0.05)$. Similar results were obtained from Sites $1,2,5$ and $10(F=0.08, p>0.05)$. No statistically significant difference was observed between the different sites in the dissolved phases $(F=0.69, p>0.05)$. Furthermore, no significant difference was observed between the dissolved and particulate phases $(F=1.46, p>0.05)$. S3 is the lake outflow and M1 is the outflow into the sea from S3. In comparing these two sites it was found that there was no significant difference in PCB concentrations $(p>0.05)$.

In terms of congener profiles, the chlorinated congeners (PCBs 52 and 153) were predominant in the water samples (dissolved plus particulate phases) and represented $49 \%$ and $44 \%$ of PCBs, respectively (Fig. 2).

PCB 52 represented 32\% of the dissolved phase. PCB 101 was detected at lower levels in all the samples with an average percentage $<10 \%$. PCB 180 represented an average of $10 \%$ in the water samples. Both hexa-CBs (138 and 153) were detected at higher levels in the particulate phase ( $24 \%$ and $28 \%$, respectively) while their contribution to the samples was $<20 \%$ each in the dissolved phase.

Statistically significant differences were observed between individual congeners $(F=22.6, p<0.05)$. PCB 153 was significantly higher than PCB 101 and 180 in the particulate phase $(p<0.05)$. Similarly, PCB 52 was significantly higher than PCB 101, 138, 153 and 180 in the dissolved phase $(p<0.05)$.

Water samples were grouped into 3 categories (Fig. 3): lake water including Sites 1, 2, 4, and 5; inflow water including Sites $6,7,8,9$, and 10 and outflow water corresponding to Sites $\mathrm{S} 3$ and M1. Specifically, tetra-CB (PCB 52) was present at higher concentrations in the dissolved phase with concentrations of 0.035 , 0.029 and $0.031 \mathrm{ng} \cdot \mathrm{L}^{-1}$ in lake water, inflow and outflow water, respectively. The hexa-CB (PCBs 138 and 153) were the most abundant congeners in the particulate phase. They were detected at an average of $0.038 \mathrm{ng} \cdot \mathrm{L}^{-1}$ in both lake water and inflow water and $0.055 \mathrm{ng} \cdot \mathrm{L}^{-1}$ in the outflow water.

All the congeners were found to be significantly higher in the outflow water than inflow and lake water $(p<0.05)$ (Fig. 3). This implies a net release of PCBs into lake water, either from sediment or atmospheric deposition. The distribution of total PCBs in water samples was: PCB $52>$ PCB $153>$ PCB $138>$ PCB $28>$ PCB 180 > PCB 101.

\section{PCB levels in mussels}

Brown mussels in the vicinity of the North End lake outflow (the sites are breakwater rocks with significant wave action) were found to contain PCBs. Table 2 summarizes the concentrations of the individual and total PCB congeners in mussel samples. The total PCB concentrations ranged from $20.85 \pm 2.57$ to 31.34 


\begin{tabular}{|c|c|c|c|c|c|c|c|c|c|c|c|c|c|c|c|c|}
\hline & & & ean cc & ncentra & ions of & idicat & PCB co & $\begin{array}{l}\text { TABLE } \\
\text { geners }\end{array}$ & and tot & PCBs i & the wa & er sam & les (ng. & & & \\
\hline & $\mathbf{P C}$ & 28 & PC & 52 & $\mathrm{PC}$ & 101 & $\mathrm{PCE}$ & 138 & $\mathrm{PCE}$ & 153 & $\mathrm{PCB}$ & 180 & Tota & PCBs & $\Sigma \mathbf{P}$ & \\
\hline Sites & $\mathrm{DP}$ & $\mathrm{PP}$ & $\mathrm{DP}$ & PP & $\mathrm{DP}$ & PP & $\mathrm{DP}$ & $\mathrm{PP}$ & $\mathrm{DP}$ & $\mathrm{PP}$ & $\overline{D P}$ & PP & $\mathrm{DP}$ & PP & $\begin{array}{c}\mathrm{DP}+ \\
\mathrm{PP}\end{array}$ & SD \\
\hline $\mathrm{S} 1$ & 0.025 & 0.015 & 0.039 & 0.019 & 0.006 & 0.008 & 0.013 & 0.037 & 0.018 & 0.025 & 0.014 & 0.010 & 0.115 & 0.114 & 0.229 & 0.011 \\
\hline S2 & 0.018 & 0.015 & 0.053 & 0.013 & 0.011 & 0.006 & 0.028 & 0.040 & 0.022 & 0.040 & 0.021 & 0.009 & 0.153 & 0.123 & 0.276 & 0.015 \\
\hline S3 & 0.029 & 0.04 & 0.025 & 0.049 & 0.003 & 0.022 & 0.015 & 0.049 & 0.011 & 0.046 & 0.019 & 0.015 & 0.102 & 0.221 & 0.323 & 0.015 \\
\hline S4 & 0.023 & 0.023 & 0.023 & 0.020 & 0.003 & 0.008 & 0.013 & 0.042 & 0.010 & 0.054 & 0.008 & 0.010 & 0.080 & 0.157 & 0.237 & 0.015 \\
\hline S5 & 0.044 & 0.012 & 0.056 & 0.014 & 0.015 & 0.007 & 0.014 & 0.025 & 0.020 & 0.040 & 0.014 & 0.008 & 0.163 & 0.106 & 0.269 & 0.016 \\
\hline S6 & 0.033 & 0.015 & 0.052 & 0.026 & 0.009 & 0.012 & 0.014 & 0.023 & 0.025 & 0.045 & 0.017 & 0.019 & 0.150 & 0.140 & 0.290 & 0.013 \\
\hline S7 & 0.021 & 0.035 & 0.033 & 0.043 & 0.006 & 0.022 & 0.023 & 0.057 & 0.018 & 0.058 & 0.011 & 0.028 & 0.112 & 0.243 & 0.355 & 0.017 \\
\hline S8 & 0.011 & 0.019 & 0.030 & 0.012 & 0.006 & 0.011 & 0.015 & 0.010 & 0.030 & 0.021 & 0.010 & 0.005 & 0.102 & 0.078 & 0.180 & 0.009 \\
\hline S9 & 0.023 & 0.017 & 0.038 & 0.018 & 0.007 & 0.011 & 0.028 & 0.011 & 0.023 & 0.013 & 0.009 & 0.005 & 0.128 & 0.075 & 0.203 & 0.010 \\
\hline $\mathrm{S} 10$ & 0.026 & 0.010 & 0.031 & 0.013 & 0.004 & 0.008 & 0.018 & 0.027 & 0.016 & 0.033 & 0.009 & 0.013 & 0.104 & 0.104 & 0.208 & 0.010 \\
\hline M1 & 0.031 & 0.023 & 0.037 & 0.048 & 0.005 & 0.012 & 0.020 & 0.056 & 0.016 & 0.072 & 0.009 & 0.014 & 0.118 & 0.225 & 0.343 & 0.021 \\
\hline
\end{tabular}

DP: dissolved phase, PP: particulate phase, SD: standard deviation. All sites had 3 replicates except for Sites 9 which had 6. Lake water was sampled at Sites S1, S2, S4 and S5, inflow water at Sites S6, S7, S8, S9 and S10 and outflow water from the lake into the sea corresponds to both Sites S3 and M1.

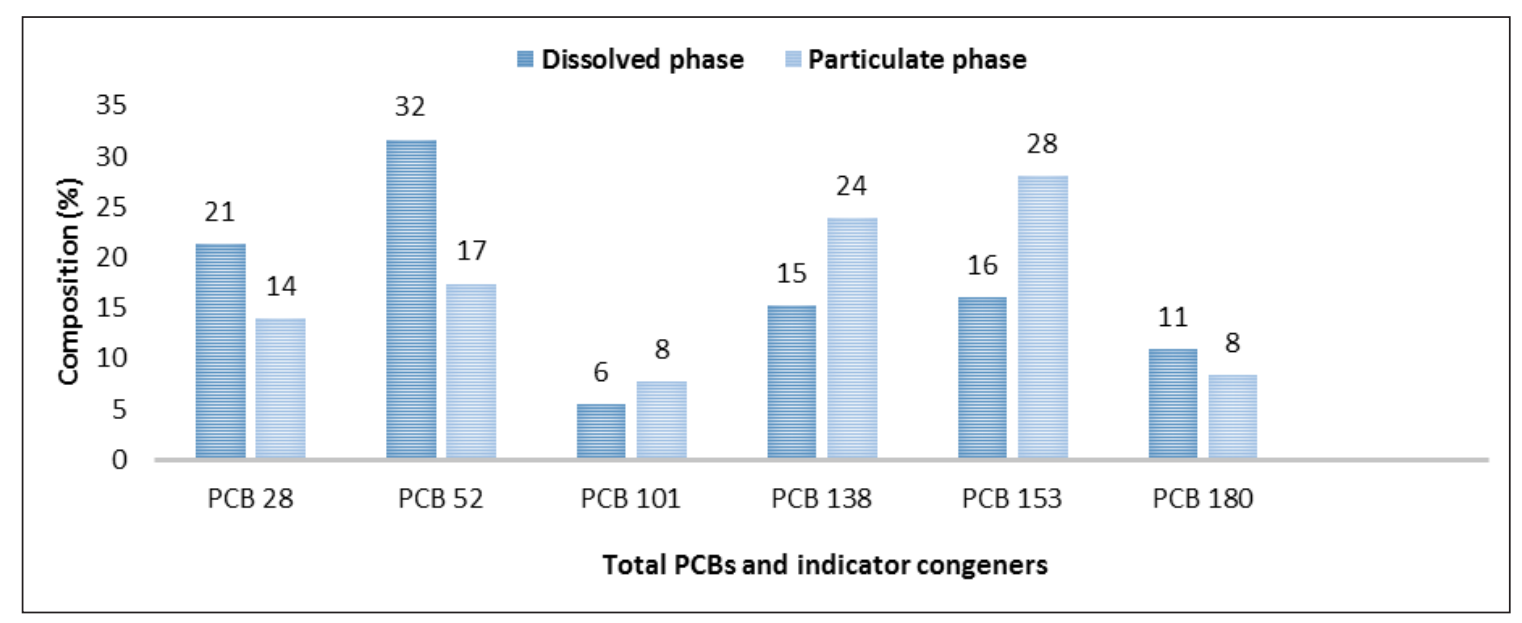

Figure 2

Percentage composition of the six indicator $P C B$ congeners in the water samples

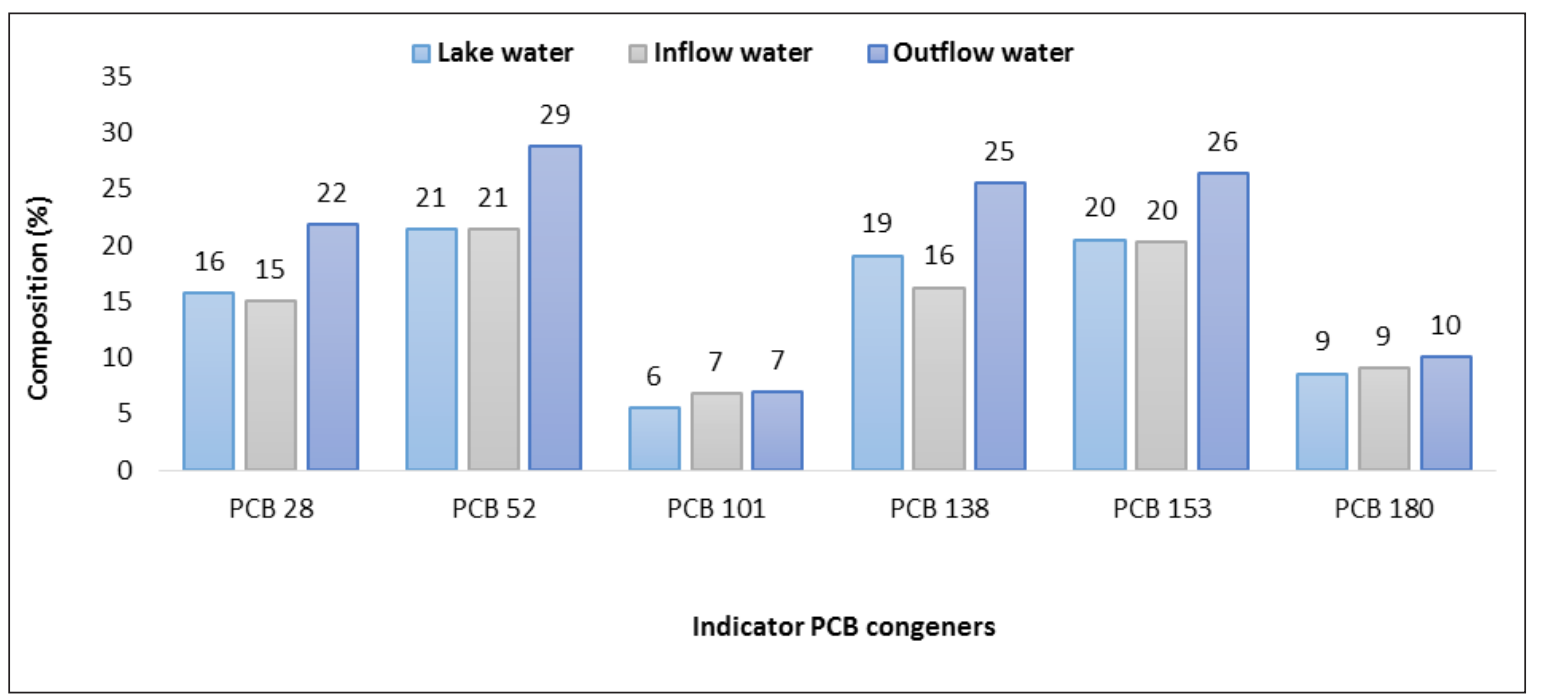

Figure 3

Composition (\%) of indicator $P C B$ congeners in lake water, inflow and outflow water samples 
$\pm 4.62 \mathrm{ng} \cdot \mathrm{g}^{-1}$ wet weight (ww). M1 (point source into the ocean) had significantly higher total PCB concentrations compared to mussels from Sites M3, M4 and M6 $(F=10.0, p<0.05)$ while M2 and M5 had higher total PCB concentrations compared to mussels from Site M4 $(p<0.05)$ only. The PCB pattern found in mussels showed a predominance of PCB-153 followed by PCB138 and PCB-52. PCBs 153 and 138 were significantly higher than PCBs 101 and 180 at Sites M1 and M2 $(p<0.05)$. The average contributions of indicator congeners to the total PCBs were $<20 \%$ for the lower congeners (PCBs 28 and 52) including PCBs 101 and 180. The hexachlorobiphenyls (PCBs 153 and 138) contributed $>20 \%$ to the total PCBs. The distribution of PCBs in mussels was: PCB $153>$ PCB $138>$ PCB $52>$ PCB $28>$ PCB $180>$ PCB 101.

\section{DISCUSSION}

The indicator PCB congeners CB-28, CB-52, -101, CB-138, CB-153 and CB-180 were detected in most of the samples. For the water samples, Sites 1 and 10 exhibited similar total concentrations of PCBs in the dissolved and particulate phases. Sites S3, S7 and M1 exhibited higher levels of PCBs in the particulate phase. The lower congeners were more concentrated in the dissolved phase while higher congeners dominated the particulate phase due to the greater solubility of lower congeners in water than the more chlorinated ones. This trend is in agreement with the work of other researchers (Schulz-Bull et al., 1998; Kurt and Ozkoc, 2004). Higher levels of total PCBs found in the water flowing out of the lake could be explained by the contamination loads from municipal and industrial wastewater discharges, atmospheric deposition and other sources of contaminants within the lake. The inflow water at Site 7 was the most contaminated, and seems to be the main source of pollution to the North End Lake. Water from this site had the highest particulate component. Sites S3 and M1 contained similar total PCB concentrations: 0.324 and $0.343 \mathrm{ng} \cdot \mathrm{L}^{-1}$, respectively.

Samples at these sites corresponded to the lake's outflow into the sea. S3 is a tunnel drain located in the proximity of the Nelson Mandela Bay soccer stadium, and Site M1 is the end of this drain into the sea. S2 which was just adjacent to the drain outlet (S3) also had high PCB levels $\left(0.276 \mathrm{ng} \cdot \mathrm{L}^{-1}\right)$. The water flowing out from the lake had higher levels of PCBs in the particulate phase than in the dissolved phase whereas the transport of PCBs to the North End Lake took place both within the aqueous phase and the suspended matter. In the water samples, tetra-CB (PCB 52) was higher in the dissolved phase while the hexa-CBs (PCBs 138 and 153) were the most abundant congeners in the particulate phase. Similar findings have been reported by Moret et al. (2005), Manodori et al. (2006), Martinez et al. (2010), and Zhang et al. (2011). In Ghana, Afful et al. (2013) and Kuranchie-Mensah et al. (2011) reported PCB-52 as one of the predominant contaminants in water samples collected from Lake Bosomtwe and Lake Weija, respectively. Generally, the lesschlorinated congeners are more water soluble and volatile while more highly chlorinated PCBs resist the degradation and volatilization and adsorb more strongly to particulate matter (Kurt and Ozkoc, 2004).

No prior research on PCB concentrations has been carried out on the North End Lake water and sea outfall. Therefore, no data are available to compare the trend of contamination in this area. In comparison to other studies, Amdany et al. (2014) reported lower levels of PCBs (0.038-0.150 ng. L-1 $)$ in the Hartbeespoort Dam (South Africa). Grobler (1994) analysed PCBs (Aroclors 1254 and 1260) in water from the Olifants River (South Africa) but no PCBs were detected. Table 3 shows a comparison of PCB levels in water from elsewhere. The levels of PCBs detected in water in the present study $\left(0.180-0.355 \mathrm{ng} \cdot \mathrm{L}^{-1}\right)$ were higher than the levels (ranging from $<0.001$ to $0.006 \mathrm{ng} \cdot \mathrm{L}^{-1}$ ) reported by Chen et al. (2008) in Three Gorges Reservoir, China, but were in the range of PCB levels detected by Wang et al. (2009) (0.08-0.51 ng. L-1 ) for the same area as Chen et al. (2008). However, other studies reported higher levels of PCBs in water than the present study (Table 3). Nasr et al. (2009) reported PCB levels in water from Egypt varying from 6.04 to $67.89 \mathrm{ng} \cdot \mathrm{L}^{-1}$ and Zhang et al. (2002) reported 33.4 to $1064 \mathrm{ng} \cdot \mathrm{L}^{-1}$ in the Pearl River Estuary. In addition, Egyptian and Ghanaian studies by Eissa et al. (2013) and Afful et al. (2013), respectively, detected higher PCB levels than the present study. Furthermore, the levels detected in water from developed countries were higher than the reported levels in the present study (Howell et al., 2008; Manodori et al., 2006; Pearson et al., 1996; Yan et al., 2008). Vogelsang et al. (2006) also monitored 5 wastewater treatment plants in Norway for 7 individual PCBs and found the total PCB concentrations varying from non-detected to $4.1 \mathrm{ng} \cdot \mathrm{L}^{-1}$.

Mussels, being filter feeders and sedentary organisms, have been widely used for the monitoring of contaminants. In agreement with the findings of Okay et al. (2009), the concentrations of PCBs in this study were predictably found to be higher in mussels compared to that of water due to the fact that the mussels have the ability to bioconcentrate organic contaminants in their tissues to very high levels. The contamination levels in mussels are related to the chemical content of the water in which they live (Potrykus et al., 2003). Figure 1 shows the location of the mussel sampling sites in the vicinity of the North End Lake outflow into the ocean. It indicates the point of release into the freshwater lake and the point of release from the lake into the marine environment.

A change in total PCB levels was observed further away from Site M1. The variation of total PCB contamination levels was in the order M4 $<$ M $3<\mathrm{M} 2<\mathrm{M} 1>\mathrm{M} 5>$ M6. This showed a drop on either side of the point source as expected.

\begin{tabular}{|c|c|c|c|c|c|c|c|}
\hline \multicolumn{8}{|c|}{$\begin{array}{l}\text { TABLE } 2 \\
\begin{array}{l}\text { Mean concentrations of individual and total PCBs } \pm \text { standard deviation }\left(n g \cdot g^{-1} \mathrm{ww}\right) \text { in mussels } \\
(n=6 \text { except for Site } 6 \text { where } n=5)\end{array}\end{array}$} \\
\hline Sites & РCB 28 & PCB 52 & РCB 101 & РCB 138 & РCB 153 & РCB 180 & $\Sigma P C B s$ \\
\hline M1 & $5.13 \pm 1.91$ & $6.98 \pm 2.60$ & $3.01 \pm 1.03$ & $6.36 \pm 1.18$ & $6.71 \pm 2.02$ & $3.16 \pm 0.30$ & $31.34 \pm 4.62$ \\
\hline M2 & $4.08 \pm 1.02$ & $5.05 \pm 1.28$ & $2.89 \pm 1.07$ & $6.07 \pm 1.2$ & $7.15 \pm 1.4$ & $3.14 \pm 0.91$ & $28.37 \pm 3.86$ \\
\hline M3 & $3.91 \pm 2.58$ & $3.52 \pm 2.09$ & $3.12 \pm 1.26$ & $3.92 \pm 1.41$ & $4.25 \pm 1.27$ & $3.15 \pm 1.14$ & $21.85 \pm 4.46$ \\
\hline M4 & $3.41 \pm 1.47$ & $3.86 \pm 1.65$ & $1.96 \pm 0.46$ & $4.80 \pm 1.40$ & $4.50 \pm 1.42$ & $2.32 \pm 0.96$ & $20.85 \pm 2.57$ \\
\hline M5 & $4.16 \pm 0.57$ & $5.10 \pm 0.92$ & $2.78 \pm 0.48$ & $6.31 \pm 0.74$ & $7.12 \pm 1.02$ & $3.40 \pm 0.94$ & $28.86 \pm 4.67$ \\
\hline M6 & $3.37 \pm 0.66$ & $5.12 \pm 1.43$ & $2.47 \pm 0.70$ & $4.87 \pm 1.22$ & $6.66 \pm 0.55$ & $2.85 \pm 0.85$ & $25.34 \pm 3.01$ \\
\hline
\end{tabular}


At these sites the prevailing east and west wind directions drive longshore currents.

It was observed that mussels were contaminated by highly chlorinated congeners (hexa-CBs 153 and 138) and the less chlorinated PCB congener CB-52, which had the highest levels at Site M1, probably due to the transfer of PCBs from water to mussels This result can be attributed to the high octanol water partition coefficient $\left(K_{\mathrm{OW}}\right)$ of PCBs which relates to less aquatic solubility, high toxicity, and bioaccumulation (Eqani et al., 2013). The log $K_{\text {ow }}$ values of PCB congeners range from an average of 4.5 for mono-CBs to 8.1 for hepta-CBs (Rapaport and Eisenreich, 1984). The higher the value of $K_{\mathrm{ow}}$ the greater the bioaccumulation either through direct partitioning or food ingestion (Patil, 1991).

The predominance of PCBs 153 and 138 reflects their persistence among the PCB congeners. Carro et al. (2000) suggested that PCBs 153 and 138 are the most dominant in biota samples.
PCB 180 was detected at lower levels in both water and mussel samples. Boon et al. (1984) attributed the lower uptake of hepta-CB to their unfavourable stereochemistry. PCB 180 has no vicinal- $\mathrm{H}$ atoms and is therefore non-metabolizable. The unfavourable stereochemistry restricts its passage through membranes (very low uptake) (Colombo et al., 1997).

In comparison with other studies on different mussel species (Table 4), levels of PCBs in Mytilus galloprovincialis detected by Kampire et al. (2015) in the Port Elizabeth Harbour (14.48 to $21.37 \mathrm{ng} \cdot \mathrm{g}^{-1} \mathrm{ww}$ ) were slightly lower than levels detected in the present study (20.84-31.40 $\left.\mathrm{ng} \cdot \mathrm{g}^{-1} \mathrm{ww}\right)$. In addition, similar total PCB levels were reported by other authors: 15.13 to 37.49 ng. $\mathrm{g}^{-1}$ ww (Salem et al., 2014) in mussels from the Mediterranean

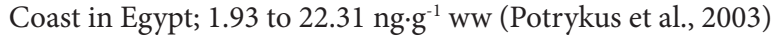
of 7 indicator PCBs in Mytilus trossulus from the Baltic Sea; 0.77 to $22.99 \mathrm{ng} \cdot \mathrm{g}^{-1}$ ww (Okay et al., 2009) of 6 indicator PCB

\begin{tabular}{|c|c|c|c|}
\hline \multicolumn{4}{|c|}{$\begin{array}{c}\text { TABLE } 3 \\
\text { Comparison of PCB concentrations in water from this study with other studies }\end{array}$} \\
\hline Locations & PCBs (ng. $\left.\mathrm{L}^{-1}\right)$ & Year & References \\
\hline Three Gorges Reservoir, China & $\begin{array}{c}<0.001-0.006 \\
0.08-0.51\end{array}$ & $\begin{array}{l}2005 \\
2008\end{array}$ & $\begin{array}{l}\text { Chen et al. (2008) } \\
\text { Wang et al. (2009) }\end{array}$ \\
\hline Baltimore Harbour, USA & $0.10-1.52$ & $1996 / 97$ & Bamford et al. (2002) \\
\hline Lake Michigan, USA & $0.34-1.74$ & 1991 & Pearson et al. (1996) \\
\hline Yangtze River, China & $0.29-2.0$ & $1998 / 1999$ & Sun et al. (2002) \\
\hline Okinawa Island, Japan & $1.59-2.48$ & 2002 & Sheikh et al. (2007) \\
\hline Campeche, Mexico & $0.07-3.40$ & 2000 & Carvalho et al. (2009) \\
\hline Bay of Bengal, India & $1.93-4.46$ & 1998 & Rajendran et al. (2005) \\
\hline Venice Lagoon, Italy & $0.45-10.5$ & 2003 & Manodori et al. (2006) \\
\hline Hudson River Estuary, USA & $0.86-6.0$ & 2001 & Yan et al. (2008) \\
\hline Alexandria Governorate, Egypt & $\begin{array}{r}0.02-6.11^{\mathrm{b}} \\
0.05-12.51^{\mathrm{a}}\end{array}$ & $2011 / 2012$ & Eissa et al. (2013) \\
\hline Houston Ship Channel, USA & $0.49-12.5$ & 2003 & Howell et al. (2008) \\
\hline Songhua River, China & $1.1-14$ & 2007 & You et al. (2011) \\
\hline Yangtze River Delta, China & $1.23-16.6$ & 2009 & Zhang et al. (2011) \\
\hline El Menofiya Governorate, Egypt & $6.036-67.89$ & $2007 / 2008$ & Nasr et al. (2009) \\
\hline Lake Bosomtwe, Ghana & $1090-7190$ & $2012 / 2013$ & Afful et al. (2013) \\
\hline North End Lake, Port Elizabeth, South Africa & $0.18-0.355$ & 2014 & Present study \\
\hline
\end{tabular}

${ }^{a, b}$ Results are expressed in $\mu g \cdot L^{-1}$; ${ }^{a}$ surface water; ${ }^{b}$ drinking water

TABLE 4

Comparison of PCB levels in mussels from the present study with other studies

\begin{tabular}{|c|c|c|c|}
\hline Locations & Mussel species & $\begin{array}{l}\text { Range of total PCB } \\
\text { levels }\left(\mathbf{n g} \cdot \mathbf{g}^{-1} \mathbf{w w}\right)\end{array}$ & References \\
\hline North End Lake, Port Elizabeth, South Africa & Perna perna & $20.54-31.40$ & Present study \\
\hline $\begin{array}{l}\text { South African Harbours (Cape Town, Port Elizabeth, Richards } \\
\text { Bay and Saldanha Bay) }\end{array}$ & Perna perna & $34-131^{a}$ & Degger et al. (2011) \\
\hline Central Adriatic Sea & Mytilus galloprovincialis & $3.43-9.81$ & Perugini et al. (2004) \\
\hline Port Elizabeth Harbour, South Africa & Mytilus galloprovincialis & $14.48-21.37$ & Kampire et al. (2015) \\
\hline Vistula and Odra estuaries, Baltic Sea & Mytilus trossulus & $1.93-22.31$ & Potrykus et al. (2003) \\
\hline Istanbul Strait, Turkey & Mytilus galloprovincialis & $0.77-22.99$ & Okay et al. (2009) \\
\hline Red Sea Coast, Egypt & Brachiodontes sp. & $6.7-66.4$ & Khaled et al. (2004) \\
\hline Mediterranean Coast, Egypt & $\begin{array}{l}\text { Lutraria elliptica and } \\
\text { Donax trunculus }\end{array}$ & $15.13-37.49$ & Salem et al. (2014) \\
\hline Mediterranean Coast, Egypt & Donax sp. & $29-37.6$ & Abd-allah et al. (1998) \\
\hline Coasts of West Mediterranean & Mytilus galloprovincialis & $5.0-60.0$ & Scarpato et al. (2010) \\
\hline Bay of Algiers, Algeria & Mytilus galloprovincialis & $64.2-185.8^{\mathrm{b}}$ & Fouial-Djebbar et al. (2011) \\
\hline Bay of Algiers, Algeria & Perna perna & $17.66-386.52$ & Chouikhi et al. (1989) \\
\hline Mediterranean Coast, Egypt & $\begin{array}{l}\text { Modiolus auriculatus and } \\
\text { Donax sp. }\end{array}$ & $8-437$ & El-Nemr et al. (2003) \\
\hline
\end{tabular}

${ }^{a}$ Results are expressed in $\mu g \cdot g^{-1}$ lipid weight; ${ }^{b}$ Results are expressed in $n g \cdot g^{1}$ dry weight. 
congeners in mussels from the Istanbul Strait, Turkey. However, other studies revealed higher levels than this study. Khaled et al. (2004) reported levels of 6.75 to $66.4 \mathrm{ng} \cdot \mathrm{g}^{-1} \mathrm{ww}$ in mussels collected along the Egyptian Red Sea coast. Scarpato et al. (2010) detected total PCBs in mussels from the coasts of the western Mediterranean Sea ranging from 5 to $60 \mathrm{ng} \cdot \mathrm{g}^{-1}$. El-Nemr et al. (2003) reported levels ranging from 8 to $437 \mathrm{ng} \cdot \mathrm{g}^{-1} \mathrm{ww}$ in mussels from Mediterranean Coast, Egypt. Degger et al. (2011) analysed the same species (Perna perna) and semi-permeable membrane devices (SPMDs) from the South African marine environment. The results showed PCB concentrations in South African harbours (Cape Town, Port Elizabeth, Richards Bay and Saldanha Bay) ranging between 34 and $131 \mu \mathrm{g} \cdot \mathrm{g}^{-1}$ lipid weight in mussels and 29 to $158 \mu \mathrm{g} \cdot \mathrm{g}^{-1}$ lipid weight in SPMDs. Degger et al. (2011) detected higher levels in mussels than in the present study. However, the results did not indicate the total amount of PCBs at each harbour. The results were also expressed in lipid weights, while in this study they are expressed in wet weights. Another study, by Chouikhi et al. (1989), found higher levels of PCBs in brown mussels (Perna perna) in the Bay of Algiers, varying from 17.66 to $386.52 \mathrm{ng} \cdot \mathrm{g}^{-1}$ fresh weight. The presence of PCBs in mussels analysed in this study may be attributed to illegal waste dumping, runoff from urban and industrial areas and industrial discharges into the North End Lake.

\section{CONCLUSION}

Water and mussels analysed were found to be contaminated by PCBs. PCB concentrations were higher in mussels than in water because bivalves are filter-feeding organisms, and can concentrate contaminants to levels well above those present in water. With the accumulation potential of these compounds in the food chain, humans are the most affected. Due to the lipophilic nature of PCBs, foods of animal origin are an important source of exposure. In drinking water, PCB levels reported typically range between 0.1 and $0.5 \mathrm{ng} \cdot \mathrm{L}^{-1}$. A person drinking $2 \mathrm{~L}$ of water a day containing $0.5 \mathrm{ng} \cdot \mathrm{L}^{-1}$ is exposed to a daily dose of $0.01-0.02 \mathrm{ng} \cdot \mathrm{kg}^{-1}$ (body weight $100-50 \mathrm{~kg}$ ) (WHO, 2000). The USA Food and Drug Administration (FDA) has set residue limits of PCBs of 2 ppm in the edible portion of mussels. The levels of PCBs detected in mussels of this study were found below the set limits of FDA. The South African regulatory limit (maximum allowable concentration) to protect human health from consumption of contaminated shellfish is set to be less than 0.02 $\mathrm{mg} \cdot \mathrm{kg}^{-1}$ (Shellfish Monitoring Programme Annual Report, 2011). The sources of PCBs in the North End Lake could be attributed to municipal and industrial discharges into the lake since it is surrounded by many industries including metal recycling, plastics, and tyre, pharmaceutical and soft drink manufacturing. The results indicated that the accumulation of PCBs depends not only on local pollution sources, but also on biological characteristics of the organism and phase (particulate matter versus dissolved). Lower PCB congeners were the most widespread in the water samples while the higher congeners were dominant in mussels. PCBs are still expected to be detected in water due to the environmental recycling of this refractory type of compound. Most of the PCBs are bound to the soil and sediments and may be released to the water slowly over a long period of time.

\section{ACKNOWLEDGEMENTS}

This work has been supported by Nelson Mandela Metropolitan University and the University of Rwanda-College of Education.

\section{REFERENCES}

ABD-ALLAH AM, ALI HA and EL-SEBAE A (1998) Level of chlorinated hydrocarbons in a teleost fish and a bivalve from the Egyptian Mediterranean Coast and Nile Estuary. Z. Lebensm. Unters. Fors. 206 (1) 25-28. http://dx.doi.org/10.1007/s002170050207

AFFUL S, AWUDZA JA, OSAE S and TWUMASI SK (2013) Persistent organochlorine compounds in the water and sediment samples from the Lake Bosomtwe in Ghana. Am. Chem. Sci. J. 3 (4) 434-448. http:// dx.doi.org/10.9734/ACSJ/2013/3913

AMDANY R, CHIMUKA L, CUKROWSKA E, KUKUCKA P, KOHOUTEK J and VRANA B (2014) Investigating the temporal trends in PAH, PCB and OCP concentrations in Hartbeespoort Dam, South Africa, using semipermeable membrane devices (SPMDs). Water SA 40 (3) 425-436. http://dx.doi.org/10.4314/wsa.v40i3.5

BABUT M, MATHIEU A, PRADELLE S, MARCHAND P, LE BIZEC B and PERCEVAL O (2012) Nationwide PCB congener pattern analysis in freshwater fish samples in France. Knowl. Manag. Aquat. Ecosyst. 40707.

BAMFORD HA, KO FC and BAKER JE (2002) Seasonal and annual airwater exchange of polychlorinated biphenyls across Baltimore Harbor and the northern Chesapeake Bay. Environ. Sci. Technol. 36 (20) 4245-4252. http://dx.doi.org/10.1021/es0206893

BERRY PF and SCHLEYER MH (1983) The brown mussel Perna perna on the Natal coast, South Africa: utilization of available food and energy budget. Mar. Ecol. Prog. Ser. 13 201-210. http://dx.doi. org/10.3354/meps013201

BEYER A and BIZIUK M (2009) Environmental fate and global distribution of polychlorinated biphenyls. Rev. Environ. Contam. Toxicol. 201 137-158. http://dx.doi.org/10.1007/978-1-4419-0032-6_5

BOON JP, OUDEJANS RCHM and DUINKER JC (1984) Kinetics of individual polychlorinated biphenyl (PCB) components in juvenile sole (Solea solea) in relation to their concentrations in food and to lipid metabolism. Comp. Biochem. Physiol C: Comp. Pharmacol. 79 (1) 131-142. http://dx.doi.org/10.1016/0742-8413(84)90175-0

BREIVIK K, ALCOCK R, LI YF, BAILEY RE, FIEDLER H and PACYNA JM (2004) Primary sources of selected POPs: regional and global scale emission inventories. Environ. Pollut. 128 (1) 3-16. http://dx.doi. org/10.1016/j.envpol.2003.08.031

CARRO N, SAAVEDRA Y, GARCIA I, IGNACIO M and MANEIRO J (2000) Distribution patterns of polychlorinated biphenyl congeners in marine sediments and wild mussels from Galicia coast (north-western Spain). J. Shellfish Res. 20 (3) 1215-1221.

CARVALHO FP, VILLENEUVE JP, CATTINI C, RENDÓN J and DE OLIVEIRA JM (2009) Pesticide and PCB residues in the aquatic ecosystems of Laguna de Terminos, a protected area of the coast of Campeche, Mexico. Chemosphere 74 (7) 988-995. http://dx.doi. org/10.1016/j.chemosphere.2008.09.092

CHEE K, WONG M and LEE H (1996) Microwave-assisted solvent elution technique for the extraction of organic pollutants in water. Anal. Chim. Acta 330 (2) 217-227. http://dx.doi. org/10.1016/0003-2670(96)00161-4

CHEN JA, LUO J, QIU Z, XU C, HUANG Y, JIN YH, SAITO N, YOSHIDA T, OZAWA K, CAO J and SHU W (2008) PCDDs/ PCDFs and PCBs in water samples from the Three Gorge Reservoir. Chemosphere 70 (9) 1545-1551. http://dx.doi.org/10.1016/j. chemosphere.2007.08.063

CHOUIKHI A, NACEUR I and TABTI D (1989) Niveaux en pesticides organochlorés et en PCBs dans les moules présentes dans la baie d'Alger. Pelagos 7 (1) 8-10.

COLOMBO JC, BROCHU C, BILOS C, LANDONI P and MOORE S (1997) Long-term accumulation of individual PCBs, dioxins, furans, and trace metals in Asiatic clams from the Rio de la Plata estuary, Argentina. Environ. Sci. Technol. 31 (12) 3551-3557. http://dx.doi. org/10.1021/es970308z

DEGGER N, WEPENER V and RICHARDSON B (2011) Brown mussels (Perna perna) and semi-permeable membrane devices (SPMDs) as indicators of organic pollutants in the South African marine environment. Mar. Pollut. Bull. 63 (5) 91-97. http://dx.doi.org/10.1016/j. marpolbul.2011.04.024 
DU PREEZ HH, HEATH RGM, SANDHAM LA and GENTHE B (2003) Methodology for the assessment of human health risks associated with the consumption of chemical contaminated freshwater fish in South Africa. Water SA 29 (1) 69-90.

EISSA F, MAHMOUD HA, GHANEM K and AHMED A (2013) Levels of polychlorinated biphenyls in surface and drinking waters in some Egyptian governorates. World Appl. Sci. J. 27 (6) 694-700.

EL-NEMR A, SAID T, KHALED A, EL SIKAILY A and ABD-ALLAH A (2003) Polychlorinated biphenyls and chlorinated pesticides in mussels collected from the Egyptian Mediterranean Coast. Bull. Environ. Contam. Toxicol. 71 (2) 0290-0297. http://dx.doi.org/10.1007/ s00128-003-0163-5

EQANI SAMAS, MALIK, RN, CINCINELLI A, ZHANG G, MOHAMMAD A, QADIR A, RASHID A, BOKHARI H, JONES K and KATSOYIANNIS A (2013) Uptake of organochlorine pesticides (OCPs) and polychlorinated biphenyls (PCBs) by river water fish: The case of River Chenab. Sci. Total Environ. 450 83-91.

FOUIAL-DJEBBAR D, DJEBBAR R, BADJAH-HADJ-AHMED AY and BUDZINSKI H (2011) Level of polychlorinated biphenyls in marine environment of Algiers Bay, Algeria. Anal. Lett. 44 (15) 2438-2456. http://dx.doi.org/10.1080/00032719.2011.551861

GROBLER D (1994) A note on PCBs and chlorinated hydrocarbon pesticide residues in water, fish and sediment from the Olifants River, Eastern Transvaal, South Africa. Water SA 20 187-194.

GUÉGUEN M, AMIARD J-C, ARNICH N, BADOT P-M,, CLAISSE D, GUÉRIN T and VERNOUX J-P (2011) shellfish and residual chemical contaminants: Hazards, monitoring, and health risk assessment along French coasts. Rev. Environ. Contamin. Toxicol. 213 55-111. http://dx.doi.org/10.1007/978-1-4419-9860-6_3

HAMMOND W and GRIFFITHS C (2006) Biogeographical patterns in the fauna associated with southern African mussel beds. Afr. Zool. 41 (1) 123-130. http://dx.doi.org/10.3377/1562-7020(2006)41[123:BPI TFA]2.0.CO;2

HOWELL NL, SUAREZ MP, RIFAI HS and KOENIG L (2008) Concentrations of polychlorinated biphenyls (PCBs) in water, sediment, and aquatic biota in the Houston Ship Channel, Texas. Chemosphere 70 (4) 593-606. http://dx.doi.org/10.1016/j chemosphere.2007.07.031

JAFFAL A, GIVAUDAN N, BETOULLE S, TERREAU A, PARIS PALACIOS S, BIAGIANTI-RISBOURG S, BEALL E and ROCHE H (2011) Polychlorinated biphenyls in freshwater salmonids from the Kerguelen Islands in the Southern Ocean. Environ. Pollut. 159 (5) 1381-1389. http://dx.doi.org/10.1016/j.envpol.2011.01.003

KAMPIRE E, RUBIDGE G and ADAMS JB (2015) Distribution of polychlorinated biphenyl residues in sediments and blue mussels (Mytilus galloprovincialis) from Port Elizabeth Harbour, South Africa. Mar. Pollut. Bull. 91 (1) 173-179. http://dx.doi.org/10.1016/j. marpolbul.2014.12.008

KHALED A, EL NEMR A, SAID TO, EL-SIKAILY A and ABD-ALLAH AM (2004) Polychlorinated biphenyls and chlorinated pesticides in mussels from the Egyptian Red Sea coast. Chemosphere 54 (10) 1407-1412. http://dx.doi.org/10.1016/j.chemosphere.2003.10.042

KUMAR B, KUMAR SSS and SHARMA C (2012) Distribution of polychlorinated biphenyls in surface waters of various sources from national capital region Delhi India. J. Nat. Sci. Res. 2 (1) 26-37.

KURANCHIE-MENSAH H, PAL, LMND, MANUKURE SA, AFFUL S, ADJEI-MARTEY G and ARTHUR JK (2011) Assessment of organochlorine pesticides and polychlorinated biphenyls levels in fishes from the Volta Lake, Ghana and their suitability for human consumption. Elixir Food Sci. 41 5982-5990.

KURT PB and OZKOC HB (2004) A survey to determine levels of chlorinated pesticides and PCBs in mussels and seawater from the Mid-Black Sea Coast of Turkey. Mar. Pollut. Bull. 48 (11) 1076-1083. http://dx.doi.org/10.1016/j.marpolbul.2003.12.013

LUTHY RG (2004) Organic contaminants in the environment: challenges for the water/environmental engineering community. In: Water and Sustainable Development: Opportunities for the Chemical Sciences - A Workshop Report to the Chemical Sciences Roundtable (p. 40). National Academies Press, Washington DC. 40.
MANODORI L, GAMBARO A, PIAZZA R, FERRARI S, STORTINI A, MORET I and CAPODAGLIO G (2006) PCBs and PAHs in sea-surface microlayer and sub-surface water samples of the Venice Lagoon (Italy). Mar. Pollut. Bull. 52 (2) 184-192. http://dx.doi.org/10.1016/j. marpolbul.2005.08.017

MARTINEZ A, WANG K and HORNBUCKLE KC (2010) Fate of PCB Congeners in an Industrial Harbor of Lake Michigan $\dagger$. Environ. Sci. Technol. 44 (8) 2803-2808. http://dx.doi.org/10.1021/es902911a

MOORE MR, VETTER W, GAUS C, SHAW GR and MÜLLER JF (2002) Trace organic compounds in the marine environment. Mar. Pollut. Bull. 45 (1) 62-68. http://dx.doi.org/10.1016/ S0025-326X(02)00104-2

MORET I, GAMBARO A, PIAZZA R, FERRARI S and MANODORI L (2005) Determination of polychlorobiphenyl congeners (PCBs) in the surface water of the Venice lagoon. Mar. Pollut. Bull. 50 (2) 167-174. http://dx.doi.org/10.1016/j.marpolbul.2004.10.005

NASR N, ARIEF M, ABDEL-ALEEM A and MALHAT F (2009) Persistent organic pollutants (POPs) in Egyptian aquatic environment. J. Appl. Sci. Res. 5 1929-1940.

NIELSEN GL and NIELSEN DM (2006) The Essential Handbook of Ground-Water Sampling: Preparing Sampling Points for Sampling: Purging Methods (2 $2^{\text {nd }}$ edn.). CRC Press/Taylor Group, Boca Raton. 99-130. http://dx.doi.org/10.1201/9781420042795.ch4

OKAY O, KARACIK B, BAŞAK S, HENKELMANN B, BERNHÖFT S and SCHRAMM KW (2009) PCB and PCDD/F in sediments and mussels of the Istanbul strait (Turkey). Chemosphere 76 (2) 159-166.

OLENYCZ M, SOKOŁOWSKI A, NIEWIŃSKA A, WOŁOWICZ M, NAMIEŚNIK J, HUMMEL H and JANSEN J (2015) Comparison of PCBs and PAHs levels in European coastal waters using mussels from the Mytilus edulis complex as biomonitors. Oceanologia 57 (2) 196-211. http://dx.doi.org/10.1016/j.oceano.2014.12.001

PATIL G (1991) Correlation of aqueous solubility and octanol-water partition coefficient based on molecular structure. Chemosphere 22 (8) 723-738. http://dx.doi.org/10.1016/0045-6535(91)90049-J

PEARSON RF, HORNBUCKLE KC, EISENREICH SJ and SWACKHAMER DL (1996) PCBs in Lake Michigan water revisited. Environ. Sci. Technol. 30 (5) 1429-1436. http://dx.doi.org/10.1021/ es940626n

PERUGINI M, CAVALIERE M, GIAMMARINO A, MAZZONE P, OLIVIERI V and AMORENA M (2004) Levels of polychlorinated biphenyls and organochlorine pesticides in some edible marine organisms from the Central Adriatic Sea. Chemosphere 57 (5) 391-400. http://dx.doi.org/10.1016/j.chemosphere.2004.04.034

POTRYKUS J, AMAYA A, PEMPKOWIAK J and PORTE VISA C (2003) Content and pattern of organic pollutants (PAHs, PCBs and DDT) in blue mussels Mytilus trossulus from the southern Baltic Sea. Oceanologia 45 (2) 337-355.

RAJENDRAN RB, IMAGAWA T, TAO H and RAMESH R (2005) Distribution of PCBs, HCHs and DDTs, and their ecotoxicological implications in Bay of Bengal, India. Environ. Int. 31 (4) 503-512. http://dx.doi.org/10.1016/j.envint.2004.10.009

RAPAPORT RA and EISENREICH SJ (1984) Chromatographic determination of octanol-water partition coefficients (Kow's) for 58 PCB polychlorinated biphenyl congeners. Environ. Sci. Technol. 18 (3) 163-170. http://dx.doi.org/10.1021/es00121a006

REGOLI F and PRINCIPATO G (1995) Glutathione, glutathionedependent and antioxidant enzymes in mussel, Mytilus galloprovincialis, exposed to metals under field and laboratory conditions: implications for the use of biochemical biomarkers. Aquat. Toxicol. 31 (2) 143-164. http://dx.doi.org/10.1016/0166-445X(94)00064-W

SALEM DMA, EL SIKAILY A and EL NEMR A (2014) Organochlorines and their risk in marine shellfish collected from the Mediterranean coast, Egypt. Egypt. J. Aquat. Res. 40 (2) 93-101. http://dx.doi. org/10.1016/j.ejar.2014.03.004

SCARPATO A, ROMANELLI G, GALGANI F, ANDRAL B, AMICI M, GIORDANO P, CAIXACH J, CALVO M, CAMPILLO JA, ALBADALEJO JB, CENTO A, BENBRAHIM S, SAMMARI C DEUDERO S, BOULAHDID, $M$ and GIOVANARDI F (2010) Western Mediterranean coastal waters-Monitoring PCBs and pesticides accumulation in Mytilus galloprovincialis by active mussel watching: the Mytilos project. J. Environ. Monit. 12 (4) 924-935. http://dx.doi.org/10.1039/b920455e 
SCHULZ-BULL DE, PETRICK, G, BRUHN R and DUINKER JC (1998) Chlorobiphenyls (PCB) and PAHs in water masses of the northern North Atlantic. Mar. Chem. 61 (1) 101-114. http://dx.doi. org/10.1016/S0304-4203(98)00010-3

SHEIKH M, NAKAMA F and OOMORI T (2007) Distribution characteristics of polychlorinated biphenyls (PCBs) in coastal areas of Okinawa Island, Japan. Chin. J. Oceanol. Limnol. 25 (3) 247-253. http://dx.doi.org/10.1007/s00343-007-0247-x

SHELLFISH MONITORING PROGRAMME ANNUAL REPORT (2011) South African Molluscan Shellfish Monitoring and Control Programme Annual Report 2010. URL: http://www.nda.agric. za/doaDev/sideMenu/fisheries/03_areasofwork/Aquaculture/ SAMSMCP/2010SMP_Report.pdf (Accessed 17 April 2015).

SUN C, DONG Y, XU S, YAO S, DAI J, HAN S and WANG L (2002) Trace analysis of dissolved polychlorinated organic compounds in the water of the Yangtze River (Nanjing, China). Environ. Pollut. 117 (1) 9-14. http://dx.doi.org/10.1016/S0269-7491(01)00169-5

TALJAARD S, VAN BALLEGOOYEN R, and MORANT P (2000) False Bay Water Quality Review, Volume 2: Specialist Assessments and Inventories of Available Literature and Data, Report to the False Bay Water Quality Advisory Committee. CSIR Report ENV-S-C 2000086/2. CSIR, Stellenbosch.

TASDEMIR Y, ODABASI M and HOLSEN TM (2005) Measurement of vapor phase deposition of polychlorinated biphenyls (PCBs) using a water surface sampler. Atmos. Environ. 39 (5) 885-897. http://dx.doi. org/10.1016/j.atmosenv.2004.10.032

VOGELSANG C, GRUNG M, JANTSCH TG, TOLLEFSEN KE and LILTVED H (2006) Occurrence and removal of selected organic micropollutants at mechanical, chemical and advanced wastewater treatment plants in Norway. Water Res. 40 (19) 3559-3570. http:// dx.doi.org/10.1016/j.watres.2006.07.022
WANG J, BI Y, PFISTER G, HENKELMANN B, ZHU K and SCHRAMM KW (2009) Determination of PAH, PCB, and OCP in water from the Three Gorges Reservoir accumulated by semipermeable membrane devices (SPMD). Chemosphere 75 (8) 1119-1127. http://dx.doi.org/10.1016/j.chemosphere.2009.01.016

WHO (2000) Air Quality Guidelines (2 ${ }^{\text {nd }}$ edn). Regional Office for Europe. Cap 5.10 PCB. WHO Regional Publications, European Series, No. 91. WHO, Copenhagen. URL: http://www.euro.who.int/ data/assets/pdffile/0005/74732/EF1922.

YAN S, RODENBURG LA, DACHS J and EISENREICH SJ (2008) Seasonal air-water exchange fluxes of polychlorinated biphenyls in the Hudson River Estuary. Environ. Pollut. 152 (2) 443-451. http:// dx.doi.org/10.1016/j.envpol.2007.06.074

YOU H, DING J, ZHAO XS, LI YF, LIU LY, MA WL, QI H and SHEN JM (2011) Spatial and seasonal variation of polychlorinated biphenyls in Songhua River, China. Environ. Geochem. Health 33 (3) 291-299. http://dx.doi.org/10.1007/s10653-010-9341-7

ZHANG L, SHI S, DONG L, ZHANG T, ZHOU L and HUANG Y (2011) Concentrations and possible sources of polychlorinated biphenyls in the surface water of the Yangtze River Delta, China. Chemosphere 85 (3) 399-405. http://dx.doi.org/10.1016/j. chemosphere.2011.07.064

ZHANG Z, DAI M, HONG H, ZHOU J and YU G (2002) Dissolved insecticides and polychlorinated biphenyls in the Pearl River Estuary and South China Sea. J. Environ. Monit. 4 (6) 922-928. http://dx.doi. org/10.1039/b206891p 